Jacek Hadryś ${ }^{1}$

Uniwersytet im. Adama Mickiewicza w Poznaniu

Wydział Teologiczny

\title{
Dążenie patronów Archidiecezji Poznańskiej do pełni życia w Bogu
}

Święci są po to, aby można było wielbić i kontemplować miłość Boga w ich życiu, uczyć się od nich owocnego podejmowania Bożej łaski (czyli zaczerpnąć pożytek duchowy dla siebie), uciekać się do ich wstawiennictwa (dzięki tajemnicy świętych obcowania), a czasami także po to, aby jak stwierdził święty Jan Paweł II, zawstydzać ${ }^{2}$. Celem niniejszego artykułu jest zaprezentowanie dążenia do pełni życia w Bogu patronów Archidiecezji Poznańskiej, czyli świętego biskupa i męczennika Stanisława ze Szczepanowa, błogosławionego biskupa i pustelnika Bogumiła oraz świętej siostry Urszuli Ledóchowskiej. Powyższą refleksję wydobyto $\mathrm{z}$ analizy zachowanych przekazów dotyczących życia tychże świętych, a w wypadku świętej Urszuli także na podstawie jej listów i pism. Dążenia poszczególnych patronów do pełni życia w Bogu zaprezentowano w sposób syntetyczny według schematu: uwarunkowania życia duchowego - najważniejsze elementy i przejawy świętości. Przy każdym umieszczono krótkie podsumowanie, a wnioski i tezy wynikające z przeprowadzonych analiz zamieszczono na końcu artykułu. Całość została poprzedzona krótkim przypomnieniem kilku podstawowych prawd dotyczących chrześcijańskiego życia duchowego i określeń jego pełni, jak również roli świętych w życiu chrześcijan; odwołano się tu do stosownej literatury przedmiotu.

\section{Zagadnienia wprowadzające}

Święty Łukasz zapisał, że Jezus „,czynił postępy w mądrości, w latach i w łasce u Boga i u ludzi” (Łk 2,52). Chrystus pełnię świętości posiadał zawsze,

${ }^{1}$ Ksiądz dr hab. Jacek Hadryś, prof. UAM (ur. w 1962 roku w Krotoszynie) - kapłan archidiecezji poznańskiej, teolog, kierownik Zakładu Teologii Moralnej, Duchowości i Katolickiej Nauki Społecznej na Wydziale Teologicznym UAM, dyrektor Szkoły Katechistów Archidiecezji Poznańskiej, cenzor ksiąg religijnych (jacekh@amu.edu.pl).

2 Por. J. Hadryś, Dynamika chrześcijańskiego życia duchowego, Poznań 2017, s. 95-100. 
niemniej wzrastał w łasce w każdej fazie swojego ludzkiego rozwoju — wybierając ludzki sposób życia, wybrał jednocześnie stopniowy wzrost ducho$w^{3}$. Chrześcijańskie życie duchowe jest rzeczywistością dynamiczną. Udział w życiu Bożym rozpoczyna się na chrzcie świętym, ale jest człowiekowi dany i jednocześnie zadany. Rozwój życia Bożego w ochrzczonym jest możliwy dzięki Chrystusowi, jednakże w praktyce zależy od współpracy człowieka z Bożą łaską. W ziemskim życiu może osiągnąć względną pełnię, by całkowitą, absolutną, posiąść w wieczności. Owa ziemska pełnia życia w Bogu jest w teologii różnie określana. Najczęściej ujmuje się ją jako pełne naśladowanie Chrystusa i upodobnienie do Niego, zjednoczenie z Bogiem, pełnienie Bożej woli, praktykę cnót, sumienne wypełnianie codziennych obowiązków ze względu na miłość do Boga, doskonałość chrześcijańską i świętość ${ }^{4}$. Naśladowanie Chrystusa i upodobnienie do Niego nie jest możliwe bez dbania o osobistą relację z Nim, co zakłada głębokie życie modlitewno-sakramentalne oraz podejmowanie z miłości ku Niemu wysiłkus, aby spełniać pragnienia Jego Boskiego Serca, czyli by miłować tak, jak On umiłował, do końca (por. $\mathrm{J} 13,1)^{6}$. Zjednoczenie z Bogiem zachodzi wtedy, kiedy wola człowieka równa się woli Bożej i nic ich nie dzieli ${ }^{7}$. Pełnienie woli Bożej ze względu na Chrystusa inspirowało rozwój duchowy wielu świętych ${ }^{8}$, a jednocześnie potwierdzało ich miłość do Niego. Życie cnotami teologalnymi oraz wysoki poziom cnót moralnych również stanowią potwierdzenie znacznego udziału w świętości Boga, gdyż bez osobistej więzi ze Zbawicielem nie byłyby możliwe. Jeżeli ktoś ze względu na Chrystusa, z miłości ku Niemu sumiennie wypełnia swoje codzienne obowiązki, nawet te najbardziej prozaiczne, to jest to także znakiem jego trwania w komunii z Bogiem. Doskonałość chrześcijanin osiąga wtedy,

${ }^{3}$ Por. J. Galot, Who is Christ? A theology of the incarnation, Roma 1980, s. 378-379.

${ }^{4}$ Zob. J. Hadryś, Różne ujęcia petni życia chrześcijańskiego [w:] Zawsze z Toba. Księga pamiatkowa ofiarowana biskupowi Zdzisławowi Fortuniakowi na pięćdziesięciolecie kapłaństwa, red. tenże, Poznań 2013, s. 243-247.

5 „Jeżeli ktoś chce pójść za Mną, niech się zaprze samego siebie, niech weźmie krzyż swój i niech Mnie naśladuje" (Mt 16,24).

${ }^{6}$ Podczas ostatniej wieczerzy Chrystus swoje postępowanie postawił za wzór do naśladowania: ,[d]ałem wam bowiem przykład, abyście i wy tak czynili, jak Ja wam uczyniłem” (J 13,15).

7 Por. Jan od Krzyża, Droga na Górę Karmel, II, 5,3 [w:] tenże, Dzieła, Kraków 1998, s. 139401, tu: s. 197. „Święty Jan od Krzyża w sposób świadomy używa terminu «unión» (zjednoczenie) zamiast «perfección» (doskonałość), by wyrazić całe bogactwo życia duchowego i jego dynamikę. Ideałem jest pełne, przekształcające i przebóstwiające zjednoczenie z Bogiem przez miłość"; J. Gogola, Teologia komunii z Bogiem, Kraków 2003, s. 101-102.

${ }^{8}$ W Dzienniczku św. Faustyny Kowalskiej znalazły się znamienne słowa: „,[o]d dziś nie istnieje we mnie wola własna [...]. Od dziś pełnię wolę Bożą, wszędzie, zawsze, we wszystkim"; taż, Dzienniczek. Miłosierdzie Boże w duszy mojej, Warszawa 2015, s. 144.

${ }^{9}$ Por. J. Gogola, Teologia komunii z Bogiem, s. 104. 
kiedy w stopniu możliwie najwyższym w ziemskim życiu miłuje Boga i ludzi, wzorując się na miłości Chrystusa do Ojca i do każdego człowieka. Pełne uczestniczenie w świętości Boga zakłada głęboką więź z Chrystusem (wymiar teologalny chrześcijańskiej świętości), która przekłada się na dostosowywanie codziennych wyborów do wymagań Chrystusa (wymiar moralny) i zakłada trwanie we wspólnocie Kościoła (wymiar eklezjalny) ${ }^{10}$. Można powiedzieć, że święty to grzesznik, który z miłości ku Bogu usilnie stara się nie grzeszyć. Powyższe stwierdzenie nie oznacza, że jest on bezbłędny moralnie, ale zakłada widoczny postęp na drodze wiodącej do upodobnienia się w miłości do Chrystusa.

\section{Święty Stanisław biskup i męczennik}

Na temat świętego Stanisława biskupa powstało wiele opracowań naukowych bądź popularnonaukowych, które odwołują się przede wszystkim do informacji podawanych przez Galla Anonima, błogosławionego Wincentego Kadłubka oraz Jana Długosza ${ }^{11}$. Gall Anonim określił biskupa Stanisława mianem buntownika wobec króla, natomiast dwaj pozostali przedstawiali go jako świętego biskupa. Aby ukazać różne przejawy świętości życia Stanisława, w niniejszym opracowaniu skorzystano z opisów sporządzonych przez Jana Długosza ${ }^{12}$. Warto pamiętać, że z wyjątkiem męczeńskiej śmierci inne wydarzenia z życia świętego Stanisława są dość słabo znane nawet historykom i hagiografom ${ }^{13}$.

10 „Świętość i doskonałość są nierozłączne. Ponieważ chrześcijanin stał się dzieckiem Bożym, świętość oznacza pełnię boskiego usynowienia, co oznacza identyfikację z Chrystusem. Owo identyfikowanie się wzrasta w życiu doczesnym poprzez praktykowanie miłosierdzia i pozostałych cnót w sprawowaniu powszechnego kapłaństwa"; J.L. Díaz, E. Burkhart, Vida cotidiana y santidad en la enseñanza de San Josemaría: Estudio de la teología espiritual, t. 3, Madrid 2011, s. 285 (thum. G. Pawlaczyk).

${ }^{11}$ Najstarszym źródłem o życiu św. Stanisława są roczniki sporządzone za czasów arcybiskupa Arona oraz Katalog Biskupów Krakowskich. Gall Anonim oraz Wincenty Kadłubek, opierając się na relacjach świadków i już istniejących przekazach, opisują wydarzenia związane ze śmiercią biskupa Stanisława. Pierwszy, w miarę kompletny życiorys świętego Stanisława powstał dopiero około 150 lat po jego śmierci, a jego autorem jest dominikanin Wincenty z Kielczy. W związku z kanonizacją zrobiono dokumentację cudów i w ten sposób powstał ważny dokument Cuda św. Stanisława (Miracula sancti Stanislai). W następnych stuleciach powstawały różne żywoty, z których najbardziej znany jest autorstwa Jana Długosza (XV wiek). Jan Długosz relację opiera głównie na Wincentym z Kielczy i ją uszczegóławia. Por. Święty Stanisław. Biskup, Męczennik. Patron Siedlec. A. Prządka (red.), Siedlce 2008, s. 9-10.

12 Wszystkie zamieszczone w przypisach cytaty z Żywota św. Stanisława Biskupa Krakowskiego Jana Długosza pochodzą z zakładki Sanktuarium ze stronie internetowej www.skalka.paulini.pl/.

${ }_{13}$ Por. Święty Stanistaw..., s. 9. 


\section{Uwarunkowania życia duchowego}

Święty Stanisław urodził się w Szczepanowie około 1030 roku. Naukę pobierał zapewne w domu rodzinnym, potem być może w Tyńcu w klasztorze benedyktyńskim. Nie jest wykluczone, że dalsze studia odbywał zgodnie z ówczesnym zwyczajem za granicą, być może w szkole katedralnej w Leodium (Liège w Belgii) lub w Paryżu. Święcenia kapłańskie przyjął około roku 1060. Dziesięć lat później został wybrany na biskupa i w 1072 roku konsekrowany. Jako biskup krakowski wyjednał u papieża Grzegorza VII wskrzeszenie metropolii gnieźnieńskiej, co uważa się za jego szczególną zasługę. Mimo wieloletniej dobrej współpracy z królem Bolesławem wszedł z nim w konflikt, wypominając popełniane przez Piasta zło i wzywając do nawrócenia. Na początku miał upominać króla w cztery oczy, a gdy to okazało się nieskuteczne, miał wygłosić na ten temat wiele kazań ${ }^{14}$. Wobec braku pozytywnej reakcji Bolesława zdecydował się rzucić na króla klątwę z nadzieją, że w ten sposób zmusi go do zmiany postępowania ${ }^{15}$. Reakcja Bolesława była odwrotna: 11 kwietnia 1079 roku osobiście zabił biskupa Stanisława podczas sprawowanej przez niego Eucharystii.

\section{Najważniejsze elementy i przejawy świętości}

Odwołując się do tekstów opisujących życie biskupa Stanisława, za podstawowe elementy i przejawy jego świętości można uznać przede wszystkim: wierność modlitwie, hojność, wolność od przywiązania do dóbr materialnych, gorliwość, roztropność, wrażliwość na potrzeby i krzywdy bliźnich, męstwo, umiłowanie prawdy, odważną obronę moralności i godności człowieka. Jan Długosz wspo-

14 „Na złe zachowanie króla narzekali wszyscy, ale lęk przed utratą majątków, urzędów lub życia powstrzymywały ich przed krytyką publiczną i upominaniem. Jeden tylko biskup krakowski usunąwszy na bok oba względy, szedł do króla nieustraszenie. Spotkawszy się z królem sam na sam w jego sypialni, wydalając wszystkich świadków, powiedział otwarcie jak szpetne i ohydne są te występki, w które król się pogrążył; [...] Prosił go i zaklinał, aby pohamował wybuchy nieokiełznanej lubieżności, aby poskromił żądze, oraz aby żył tylko z własną żoną, a nie gwałcił czystości innych małżeństw, a gdy chce, aby jego prawa były szanowane, by sam szanował praw innych. [...] Kiedy prywatne upomnienia nie dawały skutku biskup głosi w tej sprawie szereg kazań"; J. Długosz, Żywot św. Stanisława...

15 „Biskup Stanisław widział również, że wszyscy powołani do tego, boją się stanąć w obronie prawa Bożego i ludzkiego. W tej sytuacji, sam jeden, po raz drugi udał się do króla z prośbą i napomnieniem. [...] Stanisław upominał króla takimi i tym podobnymi słowami: «byłbym uciekinierem od mojej owczarni, a nie jej pasterzem, gdybym teraz nie ujął się za ludem, przeciwko twemu okrucieństwu, królu!». Stanął, więc jako wiemy pasterz i przedziwny pośrednik między ludem a królem, gdy zastawiał się za cały lud polski i całą trzodę Bożą. [...] Biskup Stanisław, zmuszony był sięgnąc po broń ostateczną — wyłączył Bolesława ze społeczności wiernych. Liczył przy tym na opamiętanie, nawrócenie i miał nadzieję z powrotem przyjąć do Kościoła, tego, którego musiał obłożyć klątwą"; tamże. 
mina, że Stanisław był bardzo zdolnym człowiekiem, z zapałem poświęcającym czas głównie na zdobywanie wiedzy oraz na modlitwę ${ }^{16}$. Już od młodości był zdyscyplinowany, nie ulegał pokusom ciała, kształtował swój charakter, odznaczał się prawością ${ }^{17}$. Z natury był otwarty na innych, stąd jako biskup przyciągał do siebie ludzi, którzy prosili o radę w sprawach duchowych czy też konkretną pomoc. Przychodzących podejmował z łagodnością i starał się im pomóc, jak to tylko było możliwe, okazując litość oraz zrozumienie ${ }^{18}$. Odznaczał się przy tym prawością i wiernością prawdzie, nie ulegał manipulacjom czy względom ludzkim, był rozsądny i uczciwy ${ }^{19}$. Swój majątek przeznaczał na pomaganie biednym bądź na budowanie kościołów ${ }^{20}$. Starał się spieszyć z pomocą możliwie największej liczbie osób ${ }^{21}$. Wierność prawdzie, nieprzeciętna odwaga oraz odpowiedzialność za tych, których Chrystus powierzył mu w biskupiej posłudze, sprawiły, że poniósł męczeńską śmierć z rąk króla Bolesława. Stała się ona ukoronowaniem jego świętego życia a jednocześnie darem dla młodego jeszcze wówczas polskiego Kościoła.

$* * *$

W świetle powyższej refleksji można stwierdzić, że droga Stanisława do świętości wiodła od dobrego wychowania w wierze w domu rodzinnym i otrzymania solidnego wykształcenia, przez pełnienie posługi biskupiej w ówczesnej

${ }^{16}$ „W nabywaniu nauk okazał, że posiada umysł pojętny, chciwy nauki i bystry, co budziło w nauczycielach wielką o nim nadzieję. Spoczynek i jedzenie mało zajmowały mu czasu. Spał i jadł krótko, zaś większość czasu przeznaczał na naukę. Jeżeli zaś miał chwilę czasu wolnego, przeznaczał go na modlitwy"; tamże.

17 „Unikał z pogardą samowolności w postępowaniu i wszelkich ponęt ciała, jakie w tym wieku występują, dając tym wielką nadzieję przyszłej prawości i siły charakteru osobistego"; tamże.

18 „Z całego królestwa zbiegali się thumnie tak duchowni jak świeccy, pragnąc oświecić się w przypadkach wątpliwych, lub prosząc o radę w potrzebach swego sumienia, których on przyjmował uprzejmie, a będąc z natury przystępnym i ludzkim, zasilał ich swoją radą i znamienitą nauką [...]. Nienawidząc wszelkiej obłudy i udawania, był prostym i otwartego serca, ceniąc i wyznając tylko samą prawdę. Był podporą ślepych, pokojem ubogich, ucieczką prześladowanych, pociechą płaczących"; tamże.

19 „Uwydatniały się w nim nadzwyczajna uczciwość, wielka powaga, wysoka skromność życia, wybitny rozsądek i oględność w słowach tak, że nigdy nie wypowiedział czegoś niepoważnego, niedojrzałego. Do każdego odnosił się z taką uprzejmą łagodnością [...]. Starał się o to i pilnował tego, aby być pomocą dla największej liczby ludzi. W radzeniu, w sądzeniu, w wyrokowaniu był umysłem człowieka nieuprzedzonego, czystego i wolnego od wszelkiego cienia dumy lub chciwości"; tamże.

20 „Całą majętność rozdawał albo na ubogich, albo na budowanie kościołów, albo na jedzenie dla głodnych. [...] Świeciła w nim głęboka pokora, trudna do wypowiedzenia łaskawość, nieograniczona litość"; tamże.

${ }^{21}$ „Pierwszym i najulubieńszym jego staraniem było podejmować się i bronić spraw ludzi uciśnionych. Zawsze był gotów dawać przytułek biednym, obronę słabym, pomoc przygnębionym jakimkolwiek nieszczęściem"; tamże. 
stolicy Polski, obdarzenie zaufaniem ze strony władzy kościelnej oraz państwowej, aż po dojrzałość do oddania życia za Chrystusa. Zwieńczeniem i dopełnieniem jego życia oddanego służbie Chrystusowi była łaska męczeńskiej śmierci.

\section{Błogosławiony Bogumil pustelnik i biskup}

Nie ma zbyt wielu informacji na temat życia Bogumiła ${ }^{22}$, jednakże te, które się zachowały, ukazują jego życie i postawę w sposób wystarczający, aby chociaż w stopniu minimalnym ukazać to, co charakteryzowało jego życie duchowe.

\section{Uwarunkowania życia duchowego}

Bogumił urodził się około roku 1135 w pobliżu Koźmina. Po uzyskaniu gruntownego wykształcenia wstąpił do zakonu cystersów. W roku 1186 został powołany na urząd biskupa w Poznaniu, a w roku 1187 został mianowany arcybiskupem gnieźnieńskim. Po dwunastu latach rządów złożył rezygnację z urzędu i przeniósł się do Dobrowa, gdzie założył pustelnię. W każdą niedzielę odprawiał msze święte dla okolicznych mieszkańców i wygłaszał kazania. Dobra rodzinne przeznaczył na misje wśród pogańskich Prusów. Zmarł w pustelni około roku 1204. Stał się chlubą zakonu cysterskiego dzięki swojej mądrości, uczynności, dzielności, świętości i hojnej fundacji na cele misyjne ${ }^{23}$.

22 „Zaledwie w dwóch źródłach historycznych wymieniany jest biskup Bogumił. Pierwsze to: «Roczniki Świętokrzyskie», z których wynika, że Bogumił w roku 1075 mianowany został arcybiskupem. W roku 1076 być może koronował na króla Polski Bolesława Śmiałego, którego poparł w sporze z biskupem krakowskim Stanisławem. Po męczeńskiej śmierci biskupa Stanisława zrzekł się urzędu i osiadł — być może dla pokuty — w Dobrowie, gdzie zmarł w roku 1092. Drugim źródłem historycznym dla życiorysu biskupa Bogumiła jest dokument z roku 1232 dotyczący nadania wsi Dobrów, cysterskiej misji wśród pogan (Kodeks Dyplomatyczny Wielkopolski, I.120). Identyfikuje się go z arcybiskupem Piotrem II, cystersem z Koprzywnicy, który od roku 1186 był biskupem w Poznaniu, później metropolitą w Gnieźnie. W roku 1198 miał złożyć swój urząd i osiadł w pustelni Dobrowie"; S. Juszczak, H. Walendowski, Błogosławiony Bogumit, [online] http://parafiaofiarowania.pl/index.php?option=com_content\&view=article\&id=80\&Itemid=96 [18.05.2018]. Zob. także M. Nowodworski, Bogumit błogosławiony [w:] Encyklopedja kościelna, t. 2, Warszawa 1873, cyt. za 2015 [online] https://pl.wikisource. org/wiki/Encyklopedja_Ko\%C5\%9Bcielna/Bogumi\%C5\%82_b\%C5\%82ogos\%C5\%82awiony [18.05.2018].

${ }^{23}$ Por. Blogosławiony Bogumit-Piotr, biskup, Internetowa liturgia godzin. Czytelnia. Święci i błogosławieni, 31 maja 2014, [online] http://brewiarz.pl/czytelnia/swieci/06-10a.php3 [18.05.2018]. 


\section{Najważniejsze elementy i przejawy świętości}

Odwołując się do informacji dotyczących życia Bogumiła oraz do zapisków błogosławionego Wincentego Kadłubka i promotora procesu beatyfikacyjnego prymasa Macieja Łubieńskiego, za najważniejsze elementy i przejawy świętości Bogumiła można uznać: pokorę, ubóstwo, zachowanie dystansu względem światowego splendoru, umiłowanie ciszy, milczenia, zamiłowanie do modlitwy, praktykowanie pokuty, a także różnorodność cnót bliżej nieznanych, w tym uczynności, dzielności i wielkiego miłosierdzia. Bogumił był człowiekiem pokornym, który nie szukał uznania u ludzi ani światowych zaszczytów, w tym kościelnych, ale umiłował życie w ciszy, odosobnieniu, poświęcone modlitwie i ascezie. O powyższym świadczy jego wstąpienie do zakonu cystersów, jak również zrezygnowanie z posługi biskupiej na rzecz prowadzenia życia pustelniczego. Ostatnie lata życia przeżył w eremie, mimo że był człowiekiem niezwykle mądrym, szlachetnym i bardzo cnotliwym ${ }^{24}$. Na szczególną uwagę w jego życiu duchowym zasługują liczne i radykalnie praktykowane umartwienia, takie jak posty i ograniczenia $\mathrm{snu}^{25}$.

$$
* * *
$$

W świetle tych nielicznych wprawdzie, ale konkretnych danych można zauważyć, że droga do świętości wiodła Bogumiła przez dobre wychowanie w wierze $\mathrm{w}$ domu rodzinnym, powołanie do życia zakonnego kontemplacyjnego w zakonie cystersów, posługę biskupią i w Poznaniu, i w Gnieźnie, aż po przebywanie w pustelni przez ostatnie pięć lat życia. Niewątpliwie błogosławionego Bogumiła cechowała duchowość pokutna i kontemplacyjna ${ }^{26}$.

\section{Święta Urszula Ledóchowska}

O Urszuli Ledóchowskiej ze względu na bliższy kontekst czasowy jest wiele informacji zarówno dotyczących biografii i posługi, jak również życia duchowego, które prowadziła. Te ostatnie dane są znane przede wszystkim z licznych listów i wypowiedzi świętej, opracowanych i udostępnionych wszystkim, którzy interesują się jej życiem i drogą do Boga. Zachowało się także wiele wspomnień o tej, która odeszła z tego świata w opinii świętości.

24 „Mąż pełny cnót i wiedzy, wyróżniający się dobrymi obyczajami, był pełen szlachetności umysłu"; Mistrz Wincenty (tzw. Kadłubek), Kronika polska, Wrocław 1996, cyt. za http://brewiarz. pl/czytelnia/swieci/06-10a.php3 [18.05.2018].

${ }^{25}$ Bogumił przebywał na pustelni ,trawiąc czas na modlitwie i trapiąc ciało swoje postami, niespaniem i różnymi umartwieniami, spędził ostatnie lata swego życia”; słowa promotora procesu beatyfikacyjnego prymasa Macieja Łubieńskiego, cyt. za Błogosławiony Bogumit-Piotr... [18.05.2018].

${ }^{26}$ Por. tamże. 


\section{Uwarunkowania życia duchowego}

Julia Ledóchowska urodziła się 17 kwietnia 1865 roku w Austrii. W 1883 roku wraz z całą rodziną przeprowadziła się do Lipnicy Murowanej niedaleko Krakowa. W 1886 roku wstąpiła do klasztoru urszulanek w Krakowie, gdzie zajęła się przede wszystkim pracą pedagogiczną. W 1907 roku razem z dwiema siostrami wyjechała do Petersburga, i objęła kierownictwo internatu dla dziewcząt przy polskim Gimnazjum św. Katarzyny. Jako obywatelka Austrii została w wyniku wybuchu pierwszej wojny światowej w 1914 roku wydalona z Rosji. Wyjechała do Sztokholmu, a następnie do Danii. Wspólnie z wyjeżdżającymi kolejno z Petersburga siostrami organizowała szkoły językowe dla skandynawskich dziewcząt, potem m.in. ochronki dla sierot po polskich emigrantach. W 1920 roku petersburska wspólnota urszulanek osiedliła się w Pniewach i wkrótce przekształciła się w apostolskie Zgromadzenie Sióstr Urszulanek Serca Jezusa Konającego. Święta Urszula w opinii świętości odeszła do wieczności 29 maja 1939 roku w Rzymie ${ }^{27}$.

\section{Najważniejsze elementy i przejawy świętości}

Za najważniejsze elementy życia duchowego świętej Urszuli i przejawy jej świętości należy uznać głęboką komunię z Bogiem, umiłowanie Chrystusa w sakramencie Eucharystii, doświadczenie krzyża i cierpienia, pełnienie woli Bożej w codzienności, życie w pełni powołaniem do życia zakonnego oraz zaangażowanie się w ewangelizację głównie przez pracę wychowawczą, apostolstwo uśmiechu, pogody ducha i radości ${ }^{28}$. Dla Matki Urszuli niezwykle ważne było trwanie w komunii z Bogiem. Święta uważała, że prawdziwe szczęście człowiek może odnaleźć tylko w Bogu, a warunkiem trwania w komunii $\mathrm{z}$ Bogiem jest prowadzenie głębokiego życia duchowego ${ }^{29}$. Owo zjednoczenie

27 J. Ledóchowska, Życie i działalność Julii Urszuli Ledóchowskiej, Warszawa 1998. Zob. M. Gryczyński, Przed kanonizacja błogosławionej Urszuli [w:] Ślady świętości. Jan Paweł II w Poznaniu i Wielkopolsce, red. J. Wiesiołowski, Kronika Miasta Poznania, wyd. specjalne, 2005, s. $160-162$.

${ }^{28}$ Por. J. Hadryś, Ewangelizacja przez radość $w$ świetle doświadczeń i pism św. Urszuli Ledóchowskiej [w:] Święta Urszula Ledóchowska: kobieta w Kościele i spoleczeństwie, red. M. Krupecka, W. Misztal, Kraków 2015, s. 117-134.

29 Por. U. Ledóchowska, List do sióstr w Petersburgu z 2 III 1915 [w:] taż, Listy do sióstr 1914-1922, Warszawa 2004, s. 129, nr 113. „Oto szczęście duszy owo trwanie w Bogu i z Bogiem. Wtedy wszystko, co ziemskie, wydaje się tak małe i nawet wśród trosk, kłopotów, bied i cierpień tego życia promień z nieba, promień pokoju, ufności i szczęścia zawsze przyświeca"; taż, Pisma zakonne, Pniewy 2000, s. 32-33. „Z Twoją, Jezu mój, przyjaźnią świat nigdy nie będzie smutny, a życie bez uroku. Obym umiała zrozumieć czyste szczęście posiadania Ciebie”; Matka Urszula Ledóchowska - czyli lekcja optymizmu, oprac. H. i B. Tofilowie, Rzym 1983, s. 76. 
z Bogiem stanowiło dla niej gwarancję najwyższego szczęścia ${ }^{30}$. W szczególny sposób Święta Urszula umiłowała jednoczenie się z Chrystusem w komunii świętej ${ }^{31}$. Szczególnie zachęcała do miłowania Chrystusa Ukrzyżowanego ${ }^{32}$. Jej zdaniem doświadczenie krzyża posiada wielkie znaczenie w życiu osoby zakonnej ${ }^{33}$. Matka Urszula była pewna, że miłość do krzyża i do Ukrzyżowanego prowadzi do szczęścia ${ }^{34}$. Kontemplowanie Ukrzyżowanego i Jego męki uważała za środek uświęcenia ${ }^{35}$. Łączyła szczęście z miłością, a miłość z doświadczeniem codziennego krzyża ${ }^{36}$. Zachęcała siostry, aby uczyły się cierpieć po Bożemu, czyli bez narzekania i zniechęcenia ${ }^{37}$. Akceptacja woli Bożej i jej wierne podejmowanie jest, według świętej Urszuli, nie tylko drogą prowadzącą

30 „Połączmy się w Nim, bo On jest dobry, On jest szczęściem najwyższym dusz naszych, On jest dla nas wszystkim. Jak to błogo Go kochać"; U. Ledóchowska, List do Marii Teresy Ledóchowskiej z 21 XII 1885 [w:] J. Ledóchowska, Listy 1885-1907. Część 1 1885-1889, Warszawa 2013, s. $56, \mathrm{nr} 40$.

31 „Dzieci najdroższe, Przenajświętszy Sakrament to słońce życia naszego, to nasz skarb, nasze szczęście, nasze wszystko na ziemi”; taż, Pisma zakonne, s. 53.

32 „Niech Wasze serca będą całe skierowane do Jezusa Ukrzyżowanego o przebitym — z miłości ku nam - Sercu. Kochajcie coraz bardziej Ukrzyżowanego, który jest wszystkim dla nas, a w Nim wszystko, wszystko znajdziecie. On pociechą i szczęściem, spokojem i ufnością, i światłem, i wszystkim”; taż, Listy do sióstr, s. 219, nr 57.

33 „Wszystko, co dobre, wzniosłe, święte w dziedzinie życia nadprzyrodzonego, z krzyża na świat spłynęło, bo to wszystko Chrystus na krzyżu męką i śmiercią swą nam wysłużył. I dlatego do krzyża dusze zakonne powinny kierować oczy swe jak kwiat do słońca. W krzyżu zbawienie, w krzyżu nadzieja nasza, w krzyżu miłość i szczęście, i wszystko nasze, bo na krzyżu Jezus Krwią Przenajświętszą nas odkupił, drzwi nieba dla nas otworzył, męką swą nam wieczną radość zapewnił"; taż, Pisma zakonne, s. 36.

34 „Pamiętajcie - w tym nasze szczęście, nasza miłość w krzyżu. Tam nauczymy się, jak kochać krzyż, choć natura jęczy, a kochając krzyż pewne jesteśmy szczęścia, bo w tym, co kochamy, nie trudno [je znaleźć]! Marne, marne radości ziemskie, choćby i dobre i czyste! To wszystko przeminie, ale z Krzyża płynie światło, co nigdy nie zgaśnie; radość, co zawsze trwa - przez wieczność całą. Kochajmy krzyż, kochajmy Ukrzyżowanego!"; taż, List do sióstr w Petersburgu z 26 II 1915, w: taż, Listy do sióstr, s. 126-127, nr 110.

35 „Wpatruj się w te oczy gasnące, wyraz niewypowiedzianego cierpienia, w rany pokrywające całe ciało. Wsłuchuj się w słowa bólu: «Boże mój, Boże, czemuś mnie opuścił!», a serce Twe rozpali się miłością do Jezusa Twego, zrozumiesz, że krzyż nawet może być źródłem szczęścia, nauczysz się powoli do krzyży życia swego wyciągać ręce”; Dzwonek św. Olafa. Wypisy, t. I, Warszawa 2000, s. 24.

36 „Szczęście zakonne rodzi się w miłości Bożej. Im więcej miłości, tym więcej szczęścia. A że chętne dźwiganie krzyża rodzi miłość, a miłość szczęście, więc dusza zakonna raduje się w tych krzyżykach, bo wie, że są dla niej źródłem miłości, a tym samym źródłem szczęścia”; U. Ledóchowska, Pisma zakonne, s. 147.

37 „Czyż nie jest dla nas radością myśl, że krzyż łączy cię coraz ściślej z Jezusem? Czyż nie jest radością, że krzyż, ochoczo dźwigany, jest najprostszą drogą do nieba? [...] Uczmy się cierpieć po Bożemu, cierpieć bez zniechęcenia, bez narzekania, bez złego humoru, bez stękania i łez — cichutko, w milczeniu, wesoło, radośnie, a cierpienie stanie się nam źródłem prawdziwego szczęścia, bo szczęścia pokuty, szczęścia miłości!"; tamże, s. 158-159. 
do świętości, ale także źródłem radości i szczęścia ${ }^{38}$. Wypełnianie woli Bożej powinno być inspirowane miłością, gdyż jest to wola Tego, który do końca umiłowa ${ }^{39}$. Święta Urszula czerpała radość z powołania zakonnego ${ }^{40}$. Życie według rad ewangelicznych traktowała jako środek i źródło szczęścia ${ }^{41}$. Wielką wagę przykładała do ewangelizowania, gdyż uważała, że najbardziej boską $z$ boskich rzeczy jest praca nad zbawieniem dusz ${ }^{42}$. Łączyła apostolską gorliwość z miłością do Chrystusa Ukrzyżowanego ${ }^{43}$, z odpowiedzią na pragnienie konającego Zbawiciela, pragnienie miłości dusz ${ }^{44}$. W apostolstwie preferowała uśmiech, radość i pogodę ducha ${ }^{45}$. Była przekonana o potrzebie i skuteczności

38 „Tylko dusza zgodna z wolą Bożą, dusza szukająca szczęścia w woli Bożej, w jasnych regionach Bożych, potrafi mimo wszystko zachować w sobie tę świeżą pogodę, to jasne, słoneczne, Boże szczęście"; tamże, s. 51.

39 „Kochajcie wolę Bożą. Zgryźcie odważnie gorzką i twardą łupinę tego rajskiego orzecha, który Bóg Wam daje: wewnątrz słodkie, szczęścia pełne jądro woli Bożej znajdziecie”; tamże, s. 49.

40 „Nie mogę sobie wyobrazić większego szczęścia na świecie, niż radość służenia Zbawicielowi w stanie zakonnym"; taż, List do Ilse von Düring z 21 XI 1887 [w:] J. Ledóchowska, Listy 1885-1907. Część 1 1885-1889, Warszawa 2013, s. 153-154, tu: s. 154, nr 102.

${ }^{41}$ Por. taż, Pisma zakonne, s. 125-126. „Kochajcie wolę Bożą, wtedy kochać będziecie i posłuszeństwo, które właśnie daje Wam możność nieustannego spełniania woli Bożej. Jaka błogość w tej myśli: Cały dzień, od rana do nocy, od nocy do rana, wiem dokładnie, gdzie dla mnie wola Boża, i z tą wolą Bożą nieustannie łączyć się mogę"; tamże, s. 29.

${ }^{42}$ „Najbardziej Boska z Boskich rzeczy — współpracować nad zbawieniem dusz”; tamże, s. 66 .

43 „Jeżeli kocham Jezusa Ukrzyżowanego, muszę odczuwać krzywdę, którą Mu grzesznicy wyrządzają, gardząc jakby Jego cierpieniami, Jego męką i śmiercią. Muszę pracować, jeśli tylko mogę, by przeciwdziałać złości świata, kochając za niego Jezusa, pocieszając Go, modląc się za nieszczęśliwych, prosząc o łaskę zmiłowania, o przebaczenie. Czy jest we mnie ta święta gorliwość, która wypływa z serca kochającego?"; taż, Rozmyślania dla Sióstr Urszulanek Serca Jezusa Konającego, Pniewy 2000, t. I, s. 272.

44 „Urszulanka Serca Jezusa Konającego powinna wsłuchiwać się w bolesną skargę wydobywającą się z ust konającego na krzyżu Pana: «Pragnę». [...] Pragnie dusz — dusz, które by Go kochały, a na które, w zamian za ich miłość, mógłby wylać skarby łask i prowadzić je do wiecznej szczęśliwości, do nieba, gdzie On dla nich miejsce chce przygotować. [...] niech w sercach Waszych tli się nieustannie święty ogień miłości dusz. Zbawić dusze, prowadzić dusze do Jezusa, dać im poznać nieskończoną dobroć Serca Jezusowego — oto ideał, dla którego poświęcić się mamy”; taż, Pisma zakonne, s. 63.

45 „Muszę być apostołką, to moje zadanie. [...] Pierwsze moje apostolstwo — to apostolstwo pogody ducha, świętej wesołości. Czy łatwo, czy trudno, czy na moim niebie słońce jasno świeci, czy też kłębią się tam ciemne chmury, czy ludzie chwalą, otaczają miłością, czy też oczerniają, prześladują - mam być zawsze pogodna i uśmiechnięta, zawsze wesoła i dobra. Choćbym nie powiedziała ani słówka, to samą pogodą ducha, uśmiechem nawet w cierpieniu, dam do zrozumienia, że dobrą rzeczą jest służyć Jezusowi, że On nasze wszystko na ziemi! Jezu, chcę głosić Ciebie, wyznawać Ciebie przed ludźmi pogodą ducha i świętym weselem"; taż, Rozmyślania..., s. 253. 
apostolstwa prowadzonego z radością i pogodą ducha ${ }^{46}$, przekonywała do podejmowania apostolstwa uśmiechu ${ }^{47}$.

$* * *$

W świetle przedłożonych refleksji można zauważyć, że droga świętej Urszuli do pełni życia w Bogu rozpoczęła się otrzymaniem w domu rodzinnym starannego wychowania w wierze, a następnie wiodła przez podjęcie powołania do życia zakonnego, ogromne zaangażowanie się w pracę wychowawczą oraz założenie i ukształtowanie nowego zgromadzenia. W swoim życiu duchowym i pełnionej posłudze Święta preferowała ufne i radosne, a także pełne uśmiechu życie apostolskie, którego podstawą było trwanie w komunii z Bogiem, jednoczenie się z Chrystusem w sakramencie Eucharystii, pełnienie woli Bożej w codzienności oraz podejmowanie codziennego krzyża.

\section{Refleksje końcowe — konkluzja}

„Pan chce [...] abyśmy byli świętymi i nie oczekuje, że zadowolimy się życiem przeciętnym, rozwodnionym, pustym" ${ }^{\prime 48}$. Te słowa papieża Franciszka z adhortacji apostolskiej Gaudete et exsultate przypominają o powszechnym powołaniu wszystkich ochrzczonych do pełni życia w Bogu. Ukazanie w niniejszym artykule duchowych sylwetek patronów Archidiecezji Poznańskiej upoważnia do sformułowania następujących konkluzji i wniosków:

46 „Pogoda ducha jest [...] bardzo skutecznym apostolstwem. Nic może tak nie przemawia do obojętnych w wierze, do niewierzących, jak widok osoby zawsze pogodnej, promiennej szczęściem wewnętrznym, uśmiechniętej, choć się wie, że niejeden krzyż dźwiga, że niejedna troska ją przygniata. To święte wesele duszy samo przez się mówi o działaniu Bożym, mówi, że jest coś ponad tą ziemią, że istnieje świat nadprzyrodzony, gdzie dusza znajduje szczęście, jakiego świat jej nie daje. Pogoda duszy pociąga do Boga, do cnoty, tak jak smutek, zły humor, kwaśne usposobienie od pobożności odstręcza"; tamże, s. 534-535.

47 „Apostolstwo, które szczególnie dziś, w naszych czasach, bardzo jest pożądane, potrzebne i skuteczne, to apostolstwo uśmiechu. Uśmiech na twojej twarzy wywołuje uśmiech na innych twarzach, a z uśmiechem wstępuje do duszy trochę radości, trochę ciepła, trochę ufności. Uśmiech rozprasza chmury nagromadzone w duszy. Uśmiech na pogodnej twarzy mówi o szczęściu wewnętrznym, mówi o pokoju czystego sumienia, o beztroskim oddaniu się w ręce Ojca niebieskiego, który karmi ptaki, przyodziewa lilie polne i nigdy nie zapomina o tych, co Jemu bez granic ufają. Uśmiech na twojej twarzy pozwala każdemu zbliżyć się bez obawy, by cię o coś poprosić, o coś spytać, bo uśmiech już z góry obiecuje chętne spełnienie prośby, grzeczną odpowiedź. Nieraz uśmiech wlewa do duszy zniechęconej, smutnej, zbolałej, jakby nowe życie, nadzieję, że nastaną lepsze czasy, że nie wszystko stracone, że Bóg czuwa"; taż, cyt. za M. Krupecka, Blisko Serca Chrystusowego. Urszula Ledóchowska i jej misja dziś, Poznań 2003, s. 44.

${ }^{48}$ Franciszek, Gaudete et exsultate. O powołaniu do świętości w świecie wspótczesnym, Rzym 2018 , nr 1 . 
1. Każdy z patronów Archidiecezji Poznańskiej przyszedł na świat w rodzinie głęboko wierzącej i praktykującej, otrzymał staranne i głębokie wychowanie $\mathrm{w}$ wierze. Ten fundament wiary stanowił mocny przyczynek w przygotowaniu każdego z nich do podjęcia świadomego życia chrześcijańskiego oraz wzięcia osobistej odpowiedzialności za rozwój własnej relacji z Bogiem. Życie świętego Stanisława, błogosławionego Bogumiła i świętej Urszuli potwierdziło ważność dobrego wychowania w wierze $\mathrm{w}$ domu rodzinnym $\mathrm{i}$ jego znaczenie $\mathrm{w}$ dążeniu do pełni życia w Bogu w dorosłym życiu.

2. Mimo różnych uwarunkowań egzystencjalnych świętych patronów łączy otrzymanie powołania do życia poświęconego Bogu. Święty Stanisław otrzymał powołanie do kapłaństwa i posługi biskupiej, święta Urszula do życia zakonnego, a błogosławiony Bogumił obydwa powołania, czyli do życia zakonnego, pustelniczego oraz do kapłaństwa i posługi biskupiej.

3. Zewnętrzne przejawy świętości u poszczególnych patronów były różne, co z jednej strony wynikało ze specyfiki powołania każdego z nich i sposobu, w jaki byli prowadzeni przez Boga, a z drugiej z życiowych uwarunkowań. U świętego Stanisława i świętej Urszuli, mimo krańcowo różnych czasów, w których dane im było żyć, można zauważyć wielkie talenty organizacyjne, bardzo przyjazne i łagodne odniesienie do bliźnich, troskę o potrzebujących pomocy i wsparcia oraz wielkość ich poświęcenia dla innych. U błogosławionego Bogumiła widoczne jest przede wszystkim umiłowanie życia ukrytego oraz praktykowanie surowej pokuty. Wszystkich troje łączy zaangażowanie się w działalność ewangelizacyjną związaną bądź to z posługą biskupią jak w przypadku świętego Stanisława i błogosławionego Bogumiła, bądź z pracą wychowawczo-formacyjną jak w posłudze świętej Urszuli.

4. W życiu duchowym u każdego ze świętych patronów uwidacznia się zamiłowanie do modlitwy, troska o trwanie w głębokiej komunii z Chrystusem, przeżywanie z Chrystusem i dla Niego doświadczenia cierpienia oraz świadomość odpowiedzialności za zbawienie innych. Owa odpowiedzialność za bliźnich szczególnie jest widoczna w posłudze świętego Stanisława oraz świętej Urszuli. Charakterystyczny dla nich jest dystans do dóbr materialnych oraz do tego, co proponuje świat, chociaż u błogosławionego Bogumiła znamienne jest fizyczne odcięcie się od życia w świecie przez rezygnację z posługi biskupiej i zamieszkanie w pustelni, a u świętej Urszuli radosna afirmacja dobra istniejącego w świecie.

5. Ze wszystkich patronów Archidiecezji Poznańskiej jedynie święty Stanisław otrzymał łaskę dosłownego oddania życia za Chrystusa. Męczeńska śmierć ujawniła i potwierdziła jego odwagę, męstwo, wierność prawdzie i misji otrzymanej od Boga i wpisała się w fundament chrześcijaństwa w Polsce. 
„Kościół się nigdy nie rozstaje z tajemnicą świętych obcowania. Nie rozstaje się ze swoimi świętymi i błogosławionymi. Oni stanowią jego przyszłość. Stanowią jego największą nadzieję. Wskazują nieustannie drogę, a równocześnie wciąż wracają do nas, są z nami. Stanowią żywy przykład dla nas"49. Te słowa świętego Jana Pawła II odnoszą się zarówno do każdego ze świętych i błogosławionych Kościoła, jak i do patronów archidiecezji poznańskiej, których sposób podejmowania łaski Bożej w życiu i posłudze nadal inspiruje wierzących w Chrystusa do świadomego i usilnego dążenia do pełni życia w Bogu.

\section{The Pursuit of the Fullness of Life in God by the Saint Patrons of the Archdiocese of Poznan}

\section{Summary}

The article presents the pursuit of the fullness of life in God by the saint patrons of the Archdiocese of Poznan, namely the saint bishop and martyr Stanislaw of Szczepanow, the blessed bishop and hermit Bogumil and the saint sister Urszula Ledochowska. The presentation is done according to the scheme: determinants of spiritual life - the most important elements and manifestations of sanctity. The inferences and assertions resulting from the conducted analyses are included in the conclusion. The study is preceded by a recapitulation of the basic truths regarding Christian spiritual life and the role of saints in the lives of Christians. Studies have shown, among other things, that each of the patrons came into the world in a family with a deep faith and received a vocation to dedicate their life to God. In saint Stanislaus and saint Urszula you can see great organizational talents, a very friendly and gentle reference to others, concern for those in need of help and support, and the greatness of their dedication to others. In blessed Bogumil, the most noticeable feature is his love for hidden life and the practice of severe penance. All three share a commitment to evangelization. Each of them reveals a passion for prayer, a concern for being in deep communion with Christ, living with Christ and for Him the experience of suffering and awareness of responsibility for the salvation of others, as well as distance to material goods.

\section{Keywords}

Archdiocese of Poznan, patron saint, saint Stanisław of Szczepanow, blessed Bogumił, saint Urszula Ledochowska, spirituality, sanctity

\section{Słowa kluczowe}

Archidiecezja Poznańska, patron, św. Stanisław ze Szczepanowa, bł. Bogumił, św. Urszula Ledóchowska, duchowość, świętość

${ }^{49}$ M. Krupecka, Z Rzymu do domu Macierzystego, 2014, [online] https://www.przewodnik-katolicki.pl/Archiwum/2014/Przewodnik-Katolicki-21-2014/Temat-numeru/Z-Rzymu-do-domu-Macierzystego [14.05.2018]. 


\section{Bibliografia}

Błogosławiony Bogumit-Piotr, biskup, Internetowa liturgia godzin. Czytelnia. Święci i błogosławieni, 31 maja 2014 [online] http://brewiarz.pl/czytelnia/swieci/06-10a.php3 [18.05.2018].

Díaz J.L., Burkhart E., Vida cotidiana y santidad en la enseñanza de San Josemaría: Estudio de la teología espiritual, t. 3, Madrid 2011.

Długosz Jan, Żywot św. Stanisława Biskupa Krakowskiego, [online] www.skalka.paulini.pl/ (zakładka Sanktuarium) [18.05.2018].

Dzwonek św. Olafa. Wypisy, t. I, Warszawa 2000.

Franciszek, Gaudete et exsultate. O powołaniu do świętości w świecie wspótczesnym, Rzym 2018.

Galot J., Who is Christ? A theology of the incarnation, Roma 1980.

Gogola J., Teologia komunii z Bogiem, Kraków 2003.

Gryczyński M., Przed kanonizacją błogosławionej Urszuli [w:] Ślady świętości. Jan Pawet II w Poznaniu i Wielkopolsce, red. J. Wiesiołowski, Kronika Miasta Poznania, wyd. specjalne, 2005, s. $160-162$.

Hadryś J., Dynamika chrześcijańskiego życia duchowego, Poznań 2017.

Hadryś J., Ewangelizacja przez radość w świetle doświadczeń i pism św. Urszuli Ledóchowskiej [w:] Święta Urszula Ledóchowska: kobieta w Kościele i społeczeństwie, red. M. Krupecka, W. Misztal, Kraków 2015, s. 117-134.

Hadryś J., Różne ujęcia petni życia chrześcijańskiego [w:] Zawsze z Tobą. Księga pamiątkowa ofiarowana biskupowi Zdzisławowi Fortuniakowi na pięćdziesięciolecie kapłaństwa, red. tenże, Poznań 2013, s. 243-247.

Jan od Krzyża, Droga na Górę karmel, II, 5,3 [w:] tenże, Dzieła, Kraków 1998, s. 139-401.

Juszczak S., Walendowski H., Błogosławiony Bogumit, [online] http://parafiaofiarowania.pl/index. php?option $=$ com_content\&view $=$ article\&id=80\&Itemid=96 [18.05.2018].

Kowalska F., Dzienniczek. Miłosierdzie Boże w duszy mojej, Warszawa 2015.

Krupecka M., Blisko Serca Chrystusowego. Urszula Ledóchowska i jej misja dziś, Poznań 2003.

Krupecka M., Z Rzymu do domu Macierzystego, 2014, [online] https://www.przewodnik-katolicki. p1/Archiwum/2014/Przewodnik-Katolicki-21-2014/Temat-numeru/Z-Rzymu-do-domu-Macierzystego [14.05.2018].

Ledóchowska J., Życie i działalność Julii Urszuli Ledóchowskiej, Warszawa 1998.

Ledóchowska U., List do Ilse von Düring z 21 XI 1887 [w:] J. Ledóchowska, Listy 1885-1907. Część 1 1885-1889, Warszawa 2013, s. 153-154, nr 102.

Ledóchowska U., List do Marii Teresy Ledóchowskiej z 21 XII 1885 [w:] J. Ledóchowska, Listy 1885-1907. Część 1 1885-1889, Warszawa 2013, s. 56, nr 40.

Ledóchowska U., List do sióstr w Petersburgu z 26 II 1915 [w:] taż, Listy do sióstr 1914-1922, Warszawa 2004, s. 126-127, nr 110.

Ledóchowska U., List do sióstr w Petersburgu z 2 III 1915 [w:] taż, Listy do sióstr 1914-1922, Warszawa 2004, s. 129, nr 113.

Ledóchowska U., Listy do sióstr 1914-1922, Warszawa 2004.

Ledóchowska U., Pisma zakonne, Pniewy 2000.

Ledóchowska U., Rozmyślania dla Sióstr Urszulanek Serca Jezusa Konającego, Pniewy 2000, t. I, s. 272.

Matka Urszula Ledóchowska - czyli lekcja optymizmu, oprac. H. i B. Tofilowie, Rzym 1983. 
DĄŻENIE PATRONÓW ARCHIDIECEZJI POZNAŃSKIEJ DO PEŁNI ŻYCIA W BOGU 247

Mistrz Wincenty (tzw. Kadłubek), Kronika polska, Wrocław 1996, cyt. za http://brewiarz.pl/czytelnia/swieci/06-10a.php3 [18.05.2018].

Nowodworski M., Bogumił błogosławiony [w:] Encyklopedja kościelna, t. 2, red. tenże, Warszawa 1873, [online] https://pl.wikisource.org/wiki/Encyklopedja_Ko\%C5\%9Bcielna/Bogumi\%C5\%82_b\%C5\%82ogos\%C5\%82awiony [14.05.2018].

Święty Stanisław. Biskup, Męczennik. Patron Siedlec, red. A. Prządka, Siedlce 2008. 